\title{
UN PROBLEMA DE HOMONIMIA: RECONSIDERANDO AL ESCULTOR PEDRO ROLDÁN, EL MOZO*
}

\section{A PROBLEM OF NAMESAKE: RECONSIDERING THE SCULPTOR PEDRO ROLDÁN, THE YOUNGER}

\author{
Manuel García Luque \\ Universidad de Granada. España \\ mgarcialuque@ugr.es
}

\begin{abstract}
En el artículo se propone una revisión de la figura de Pedro Roldán “el Mozo" (1665-1720), hijo del famoso escultor Pedro Roldán, con quien a veces se le confunde en la documentación. Aquí se restituyen al hijo algunas noticias y obras hasta ahora consideradas del padre, al tiempo que se distingue de un tercer homónimo vecino de la villa de Espera. Sus tempranos trabajos para Luque, Lucena y Archidona demostrarían su voluntad de establecerse como escultor independiente con anterioridad a la muerte del padre.

Palabras clave: Barroco; escultura policromada; Roldán el Mozo, Pedro; Sevilla; Jaén
\end{abstract}

This article reviews the figure of Pedro Roldán 'the Younger' (1665-1720), son of the famous Sevillian sculptor Pedro Roldán, with whom he is sometimes confused. Some news and works considered by the father are restored to the son, who is also distinguished from a third homonymous resident of the village of Espera. His early works for Luque, Lucena and Archidona demonstrate his willingness to establish himself as independent sculptor even before his father's death.

Keywords: Baroque; polychrome sculpture; Roldán 'the Younger', Pedro; Seville; Jaén

Uno de los principales inconvenientes de la investigación sobre Edad Moderna en España es el de la homonimia, pues hasta la implantación del Código Civil en 1870 no existió ninguna norma que regulara el uso de los apellidos ${ }^{1}$. En el Antiguo Régimen

* Trabajo realizado en el marco del proyecto I+D "El triunfo del barroco en la escultura andaluza e hispanoamericana" (HAR2013-43976-P) financiado por el Ministerio de Economía y Competitividad.

${ }^{1}$ Exceptuando, claro está, las cláusulas de algunos títulos nobiliarios y mayorazgos, que sí podían establecer alguna prelación en el uso de los apellidos. 
cada cuál podía tomarlos a conveniencia, especialmente si se trataba de dar lustre o incluso falsear el origen de los antepasados, en un mundo - no olvidemos-donde el estigma de proceder de conversos o penitenciados lastraba cualquier intento de ascenso social. De este modo podían tomarse los apellidos del padre, de la madre o de cualquier familiar a mano; se da el caso incluso de hermanos que no comparten patronímico o de personajes que van cambiando de apellidos a lo largo de su trayectoria vital.

La mayoría de las ocasiones, los problemas de homonimia pueden ser sorteados con un simple cotejo de firmas y, en su ausencia, apoyándose en la información suministrada por la documentación notarial, donde a menudo se hace constar la naturaleza, vecindad, collación y oficio de los otorgantes ${ }^{2}$. Cuando se trata de homónimos en la misma familia, a veces se diferencian apelando a su edad, asociándose calificativos como "el viejo/el joven" o "el mayor/el menor". Lamentablemente éste no fue el caso del escultor Pedro Roldán (1665-1720) , a quien solo modernamente la historiografía ha terminado denominando "el Mozo" para distinguirlo de su padre, el también escultor Pedro Roldán (1624-1699)4. La circunstancia de compartir nombre, oficio y a veces incluso vecindad y collación ha contribuido notablemente a oscurecer su memoria, pues ha existido la tendencia de identificar con el padre cualquier noticia suya anterior a 1699. El caso, además, se agrava si consideramos que su sobrino, el también escultor Pedro Duque Cornejo, recibió el nombre de "Pedro Roldán" en alguna ocasión", sin olvidar la existencia de otros homónimos ajenos a la familia, como fue el caso de un vecino de la villa de Espera (Cádiz).

${ }^{2}$ Un caso similar de homonimia es analizado por VILLAR MOVELLÁN, Alberto: "Homónimos de Juan de Mesa", Apotheca, 4, 1984, pp. 109-151.

${ }^{3}$ Sobre el autor en cuestión, que carece de estudios monográficos, es imprescindible la consulta del espacio que se le dedica en los estudios del taller de su padre: SALAZAR, María Dolores: "Pedro Roldán, escultor", Archivo Español de Arte, t. XXII, 1949, p. 323; SANCHO CORBACHO, Heliodoro: El escultor sevillano Pedro Roldán y sus discípulos. Sevilla, 1950, pp. 34-36; BERNALES BALLESTEROS, Jorge: Pedro Roldán: Maestro de Escultura (1624-1699). Sevilla, 1973, pp. 31-36; TORREJÓN DÍAZ, Antonio: "El entorno familiar y artístico de 'La Roldana': el taller de Pedro Roldán”, en ROMERO TORRES, José Luis y TORREJÓN DÍAZ, Antonio (coms.): Roldana [cat. exp.]. Sevilla, 2007, pp. 71-72; y finalmente el más reciente y excelente trabajo de RODA PEÑA, José: Pedro Roldán: escultor (1624-1699). Madrid, 2012, pp. 186-188.

${ }^{4}$ Tan sólo encontramos una referencia documental que lo distinga en el contrato de las columnas de la iglesia del Buen Suceso, en 1690, donde figura junto a su padre y se le denomina "Pedro Roldán el menor en dias". LÓPEZ MARTÍNEZ, Celestino: Retablos y esculturas de traza sevillana. Sevilla, 1928, p. 119.

${ }^{5}$ Así se le nombra en 1699 (cuando contaba 20 años) en la escritura de concierto otorgada por Juan del Castillo para hacer el retablo de la capilla de la Soledad en la iglesia de Santa María de la Mota en Marchena. ARENILLAS, Juan Antonio: "Juan del Castillo, un escultor del siglo XVIII en Marchena", Atrio, 1, 1989, p. 82. 
Este sencillo trabajo pretende poner un poco de orden sobre la escasamente conocida figura de Pedro Roldán el Mozo, distinguiéndolo de sus homónimos y restituyéndole algunas noticias y trabajos. Estas nuevas evidencias permiten refutar la tradicional creencia de su inactividad como escultor independiente hasta la muerte del padre.

\section{LA EMANCIPACIÓN DE LOS MIEMBROS DEL TALLER DE PEDRO ROLDÁN}

Una de las claves del éxito de Pedro Roldán el Viejo fue la de contar con un amplio taller de fuerte componente familiar, en el que prácticamente todos los hijos trabajaban a su servicio, ya fuera como escultores (Marcelino, María, Luisa y Pedro) o pintores (Francisca) ${ }^{6}$. Además, se dio la circunstancia de que la mayoría de las hijas acabaron casándose con otros tantos escultores, presumiblemente formados en el taller paterno. Es conocida la repetida oposición del viejo Roldán a estos matrimonios, lo que da buena cuenta de su fuerte carácter, pero también puede ser revelador del miedo a la progresiva emancipación de los componentes de su taller, como finalmente acabó ocurriendo ${ }^{7}$.

La primera en escapar de la sombra del padre fue Luisa (1652-1706), casada con el escultor Luis Antonio de los Arcos en 1671, junto a quien comienza a trabajar de manera independiente. Por si fuera poco, en 1687 ambos abandonan la capital hispalense, poniendo primero rumbo a Cádiz y luego a la Corte, donde Luisa logró la distinción más anhelada por cualquier escultor del momento: trabajar para el rey, como escultora de su cámara. A este reconocimiento hay que sumar el que, casi a título póstumo, le brindó la Academia romana de San Lucas al nombrarla académica de mérito ${ }^{8}$.

La biografía de su hermano Marcelino (1662-1709) encuentra puntos de contacto con la vida de la Roldana, pues él también se encontraba en Cádiz entre 1686-1687 y consiguió asimismo el título de escultor del rey Felipe V en julio

${ }^{6}$ Los hijos de Pedro Roldán, como continuadores del padre, siempre han ocupado un lugar específico en los trabajos monográficos de este escultor. Véanse los trabajos citados en la nota 3, especialmente el de TORREJÓN DÍAZ, Antonio: "El entorno familiar y artístico...”, op. cit., pp. 53-77, y la más reciente revisión dada por RODA PEÑA, José: Pedro Roldán..., op. cit., pp. 176-189.

${ }^{7}$ Pedro Roldán se opuso primero al matrimonio de su hija Luisa con el escultor Luis Antonio de los Arcos en 1671; luego al de su hija Francisca con el escultor José Duque Cornejo en 1677; y finalmente al de su hija Ana Manuela (de la que se desconoce si fue artista) con el escultor José Fernández de Arteaga en 1688. Cfr. TORREJÓN DÍAZ, Antonio: "El entorno familiar...", op. cit., pp. 62-69.

${ }^{8}$ HALL VAN DEN ELSEN, Catherine: "Luisa Roldán, la Roldana: aportaciones documentales y artísticas”, en Roldana..., op. cit., p. 26. 
de $1701^{9}$. Pero a diferencia de su hermana, la producción y el estilo de Marcelino aún siguen siendo puntos oscuros, dado lo poco que ha sobrevivido de su ya de por sí exiguo catálogo.

Otro tanto podría decirse de María Josefa Roldán (1654-ca.1716), cuya actividad discurre paralela a la de su marido Matías de Brunenque, un escultor posiblemente formado en el taller de Roldán. Lo ínfimo del catálogo de ambos es un probable indicador de que el matrimonio continuó al servicio de Pedro Roldán aun después de su enlace. Efectivamente, en la década de 1670 aparecen avecindados en la placeta de Valderrama, donde vivía la mayor parte de la familia y Pedro Roldán tenía instalada su vivienda y taller. Sin embargo, el cambio de domicilio que efectuaron en 1681, para trasladarse a la calle Correduría, fue interpretado por Antonio Torrejón como un probable indicio de su emancipación del obrador familiar ${ }^{10}$.

\section{PEDRO ROLDÁN EL MOZO EN JAÉN Y SU ACTIVIDAD EN EL SUR DE CÓRDOBA (1683-1686)}

Respecto al benjamín de la familia se había señalado que su trayectoria como escultor independiente nunca llegó a despegar hasta la muerte de su padre, pues hasta 1699 solo se le conocían dos trabajos en piedra, abordados en compañía de Roldán el Viejo: por un lado, su más que probable participación en las nueve esculturas para coronar la fachada de la catedral de Jaén (1683-1684) ${ }^{11}$; y, por otro, su constatada intervención en la labra de las veinticuatro columnas de jaspe para la iglesia sevillana del Buen Suceso (1690) ${ }^{12}$. Sin embargo, al igual que sus hermanos, parece que Pedro Roldán el Mozo también estuvo tentado de iniciar su actividad en solitario en el entorno de Jaén y el sur de Córdoba en la década de 1680.

Su relación con el medio artístico giennense se remonta a 1675, cuando su padre obtuvo el encargo de esculpir cuatro relieves en piedra para la fachada principal de la catedral, que por entonces se estaba levantando bajo la dirección del maestro Eufrasio López de Rojas (Figura 1). El programa se completaría dos años más tarde con dos estatuas de San Pedro y San Pablo, y finalmente en 1683 con el encargo de otras nueve, representando a los Padres de la Iglesia Latina, los Evangelistas y San Fernando, para ser exhibidas sobre la balaustrada. Son bien significativas las diferencias de calidad entre este último lote y las dos figuras de

9 TORREJÓN DÍAZ, Antonio: “El entorno familiar...”, pp. 71 y 77, n. 86, donde cita la tesis doctoral inédita de Catherine Hall van den Elsen.

${ }^{10}$ Ibídem, pp. 67-68.

${ }^{11}$ A esta deducción llega GALIANO PUY, Rafael: "Las esculturas de la catedral de Jaén (S. XVII). Corpus documental y fotográfico", Boletín del Instituto de Estudios Giennenses, 195, 2007, p. 127, tras descubrir su presencia en Jaén.

12 LÓPEZ MARTÍNEZ, Celestino: Retablos y esculturas..., op. cit., p. 119. 
los Apóstoles -en las que se aprecia la intervención personal del maestro-, lo que resulta hasta cierto punto comprensible teniendo en cuenta que se hicieron para un emplazamiento más elevado y que se pagó por ellas un precio considerablemente menor (Figuras 2 y 3). En el equipo de escultores que se encargaron de su talla debía encontrarse Pedro Roldán el Mozo, que por entonces rondaría los 18 años y estaría a punto de alcanzar la maestría, si es que no la había logrado ya. No está claro si el muchacho acompañó a su padre en el viaje que éste hizo a Jaén en mayo de 1683 para formalizar el contrato con el cabildo, o bien se desplazó a posteriori una vez que los canteros tuvieron la piedra preparada para iniciar las labores escultóricas. Una vez terminada esta empresa, en abril de 1684, Pedro Roldán el Viejo retornaría a Sevilla, mientras que su hijo tuvo que permanecer en Jaén, pues tres meses más tarde, el 5 de julio, contrajo matrimonio con Paula María Romero de Bárcena en la parroquia de San Ildefonso ${ }^{13}$.

El menor de los Roldán mantuvo durante algunos años más su residencia en la capital giennense, pues hasta el 3 de febrero del año siguiente no tuvieron lugar sus velaciones matrimoniales. Aún debió de continuar viviendo allí, al menos, hasta el 3 de agosto de 1686, cuando se otorgaba la carta de dote y arras del matrimonio ${ }^{14}$. Si aceptamos que el joven Pedro pudo acudir a Jaén junto a su padre en mayo de 1683 y que en aquel tiempo estableció su residencia en la ciudad, este período giennense comprendería como mínimo tres años, en los cuales acabó adquiriendo carta de vecindad.

Al menos así lo demuestra el que el 16 de enero de 1686 se declarara vecino de Jaén en una escritura notarial. Aquel día el ya "maestro de escultura" se encontraba en la villa cordobesa de Luque, otorgando escritura de obligación para la realización de las esculturas del retablo mayor de la iglesia parroquial de Nuestra Señora de la Asunción, recientemente finalizado en lo que a ensambladura se refiere por el retablista cordobés Acisclo Manuel Muñoz ${ }^{15}$. Lo cierto es que antes de la conclusión de este gran retablo salomónico, la fábrica ya había concertado su programa iconográfico con Manuel de Miranda, escultor avecindado en Córdoba, en 1683. Agotados tres de los cuatro años del plazo que se le había dado al artista para la entrega, parece que Miranda había "faltado al cumplimiento deste contrato" y "hecho fuga", lo que motivó la búsqueda de un escultor alternativo que se hiciera cargo de la obra ${ }^{16}$. No está claro si el artífice llegó a entregar alguna

${ }^{13}$ GALIANO PUY, Rafael: "Las esculturas de la catedral...”, op. cit., p. 127.

14 Ibídem.

15 ESTRADA CARRILLO, Vicente: La iglesia parroquial de Luque (1567-1992). Córdoba-Luque, 1993, pp. 83-86. Cfr. nota 18.

${ }^{16}$ Ibídem, pp. 86-87. La anotación se hace en las cuentas de 1687, aunque todo hace indicar que con anterioridad los promotores ya fueron conscientes del probable incumplimiento, pues de otro modos no se explicaría que reclamaran los servicios de Roldán el Mozo un año antes. 
imagen antes de su abandono, aunque Estrada Carrillo considera suyos el San Pedro, el San Pablo y también el Crucificado, pero este último es claramente obra granadina de Pablo de Rojas o su círculo ${ }^{17}$.

La nueva escritura de concierto de Pedro Roldán el Mozo contemplaba ciertas mejoras sobre el contrato original, pues se incrementaba en seis el número de esculturas: ahora serían diez de tamaño natural (dos varas, aprox. $167 \mathrm{~cm}$ ) y otras seis de pequeño formato (tres cuartas, aprox. $63 \mathrm{~cm}$ ). Como es habitual, el contrato no indica su iconografía, limitándose a señalar que se trataba de "hechuras de santos" ${ }^{18}$. A pesar de esta ampliación del programa escultórico, Pedro Roldán tan solo recibiría por su trabajo algo menos de la mitad del precio estipulado en el primer contrato (apenas 600 ducados, es decir, 6.600 reales, en lugar de los 13.500 pactados con Miranda) pero hay que tener en cuenta que en esta ocasión la fábrica parroquial quedaba obligada a suministrarle la madera aserrada, seguramente aprovechando la ya aparejada por Manuel de Miranda ${ }^{19}$.

En cualquier caso, el vicario de Luque, don Francisco Blanco de Canova, dejaba bien claro que la firmeza de este acuerdo quedaría sujeta al beneplácito del provisor del obispado, en nombre del deán y cabildo de la catedral de Córdoba. No sabemos si fue por la negativa de la autoridad eclesiástica, por desistimiento del propio escultor o por la falta de liquidez de la parroquia -que acababa de desembolsar 44.000 reales en la construcción del retablo-, pero todo apunta a que el encargo nunca llegó a tener efecto. Después del otorgamiento de esta escritura, no se vuelve a tener constancia de la presencia de Pedro Roldán el Mozo en Luque, ni se le documenta pago alguno en las cuentas de fábrica. De hecho, el programa iconográfico del retablo no vería su conclusión hasta 1705, cuando el escultor granadino Atanasio Tribaldos se comprometa a realizar la esculturas que faltaban ${ }^{20}$.

17 Íbid.

${ }^{18}$ LUQUE CARRILLO, Juan: "El Retablo de Luque (Córdoba): un proyecto de Pedro Roldán 'el Mozo' y otros datos”, BSAA Arte: Boletín del Seminario de Estudios de Arte, 80, 2014, pp. 211-218.

19 Aunque en los pagos de 1683 consta que Manuel de Miranda se desplazó desde Córdoba, es probable que más adelante trasladara su taller a Castro del Río. Allí se encontraba la madera en 1697, pues en las cuentas de fábrica de la parroquia de Luque se registra el gasto de 19 reales "en el biaxe que hizo este obrero a la villa de Castro a traer en dos carretas la madera de los santos que estaba en dicha villa de ésta", así como 24 reales "que declaró auer pagado a don Cristóbal Caluo por el arquiler de una carretta y un carrettero que dio para yr a la villa de Castro a traer unas efixies y caxas de madera que estauan en esta villa en poder del ... [vecino] y un banco de carpintero, cuias echuras las enpezó Juan [sic] de Miranda". ESTRADA CARRILLO, Vicente, La iglesia parroquial..., op. cit., p. 87.

${ }^{20}$ Ibídem, pp. 87-88 y n. 27. Son las esculturas de San Bartolomé, Santiago, la Inmaculada y dos ángeles. 
Tras su estancia en la villa de Luque, Pedro Roldán el Mozo tuvo que pasar a la cercana ciudad de Lucena, donde también se reclaman sus servicios para hacerse cargo de otra obra abandonada por un escultor fugado. Allí se encuentra el 28 de febrero de 1686, cuando otorga carta de pago por la realización de un San Francisco de Paula de talla para el regidor y alguacil mayor don Gerónimo Gil Guerrero, comisario de la obra de la ermita que el cabildo de la ciudad había votado erigir al santo con motivo de la epidemia de peste de $1679^{21}$. Según se aclara en el documento, en principio la comisión escultórica le había sido encomendada a un escultor llamado Juan Caballero, del que nada más sabemos ${ }^{22}$, quien "abiendo empezado a disponer dicha echura se ausento desta ciudad sin aberla acabado”. Ante este imprevisto, don Gerónimo Gil Guerrero apremió a los fiadores del escultor, Juan Navajas y Bartolomé Ramírez, a que "buscasen persona y maestro del dicho arte que cumpliese con dicha obligazion, los quales conduzieron a esta ziudad al dicho Pedro Roldan para que acabase dicha echura en toda perfeczion" 23.

La presencia en Lucena del menor de los Roldán no se debía, por tanto, a una iniciativa del promotor de la obra, sino a la única salida que hallaron sus fiadores. Si Bartolomé Ramírez pasa por ser un completo desconocido, Juan Navajas (o Rodríguez Navajas), debe ser el cantero del mismo nombre, más conocido por ser tío materno del famoso arquitecto lucentino José de Bada y Navajas, maestro mayor de las catedrales de Granada y Málaga ${ }^{24}$. Es probable que este cantero se

${ }^{21}$ Sobre esta ermita, véase LÓPEZ SALAMANCA, Francisco: "Apuntes sobre la iglesia y convento de San Francisco de Paula (I y II). Los orígenes: Una grave epidemia", San José Artesano (Lucena), 20, 2007, pp. 19-23; y 21, 2008, pp. 13-17; PALMA ROBLES, Luisfernando: "San Francisco de Paula y Lucena en la Centuria del Seiscientos (II)", San José Artesano (Lucena), 20, 2007, pp. 29-30 y del mismo autor "Una crónica del Seiscientos: San Francisco de Paula y la ciudad cordobesa de Lucena (Córdoba)", Crónicas de Canarias, 6, 2010, pp. 311-313.

${ }^{22}$ Como motivo de especulación, pudiera tratarse de un hermano de Manuel Caballero, primer marido de Teresa Roldán, del que se desconoce profesión. SALAZAR, María Dolores: "Pedro Roldán...", op. cit., p. 323.

${ }^{23}$ Véase la transcripción íntegra del documento en el apéndice. Fue citado por primera vez en SERRANO TENLLADO, María Araceli: El poder socioeconómico y político de una élite local: los regidores de Lucena en la segunda mitad del siglo XVII. Córdoba, 2004, p. 376, aunque sin identificar la escultura ni a su autor con Pedro Roldán el Mozo.

24 Juan Navajas se desposará dos años más tarde en Cabra con la viuda María Enríquez, y para entonces ya debía estar integrado, junto a su hermano Francisco, en el taller egabrense de Melchor de Aguirre. Marchado éste a Granada, Juan se avecindará de nuevo en Lucena, desde donde trabajará para la ciudad y la capital. En Lucena se le documenta labrando la portada del convento de Santa Ana (1692), la torre de la ermita de la Virgen de Araceli y en el camarín de Nuestra Señora del Valle. En 1695 se compromete a llevar piedra roja al Santuario de la Fuensanta de Córdoba. Junto a su cuñado Toribio de Bada contrata el retablo marmóreo de los alcantarinos, y más tarde el retablo de la parroquia de San Miguel (1701) y la portada de ermita de la Alegría (1702). Cfr. TAYLOR, 
ocupara de labrar el frontal de altar de la nueva ermita, por lo que cabría especular que Ramírez se hubiera ocupado del ensamblaje del retablo y Caballero de la hechura del santo.

Este cambio de maestro escultor supuso un sobrecoste, pues el comitente hubo de pagar 50 reales más de lo estipulado inicialmente (900 reales), en tanto que los fiadores tuvieron que poner de su bolsillo otros 150 reales "por aberles sacado de la obligazion que tenian echa con el dicho Juan Caballero". De este modo, el joven Pedro Roldán -que también en esta ocasión se declara vecino de Jaén, aunque residente en Lucena- recibió en total 1.100 reales de vellón, una cantidad desde luego nada desdeñable si se tiene en cuenta que se trataba de una sola escultura y que, además, ésta ya estaba comenzada, con el consiguiente ahorro de material.

La imagen, aunque pagada por el regidor, en realidad fue costeada con dinero de las arcas municipales, al igual que el resto de ornamentos y pinturas de la vida del fundador de los mínimos que decoraban la ermita ${ }^{25}$. La escultura que realizó Pedro Roldán estaría destinada a ocupar una hornacina lateral del altar mayor, donde haría pareja con otra imagen de San Nicolás de Bari, donada por la duquesa de Medinaceli, quien asimismo costeó la pintura de la Soledad que centraba el altar' ${ }^{26}$.

René: Una obra española de yesería. El sagrario de la parroquia de San Mateo de Lucena. México, 1978, p. 35; VALVERDE MADRID, José: Ensayo socio-histórico de retablistas cordobeses del siglo XVIII. Córdoba, 1974, p. 26.; RIVAS CARMONA, Jesús: Arquitectura barroca cordobesa. Córdoba, 1982, p. 69 y Arquitectura y policromía. Los mármoles del Barroco andaluz. Córdoba, Diputación, 1990, pp. 81-82; BAREA LÓPEZ, Óscar: Heráldica y genealogía de Cabra de Córdoba, Doña Mencía y Monturque y de sus enlaces (ss. XV$X I X)$. Bubok, 2012, t. II, p. 46.

25 AHPCo (Archivo Histórico Provincial de Córdoba), Protocolos Notariales (PN) de Lucena, Oficio de Francisco Tenllado Navarrete, 1734, leg. 2664P, f. 11v: "Dio y entregó esta Muy Noble y Leal Ziudad con magnanima debota liberalidad âl Reverendisimo Padre fray Juan de Cardenas, entonzes vicario prouinzial y a los Padres que trajo y formaron dicho ospizio, desde luego para el vso de el, y para el de sus exercizios religiosos, no solo la dicha yglesia nueba, dezente, vien tratada y adornada toda de muchas y buenas pinturas de la vida de el milagroso santo, que aun oy se conserban en ella, con dos campanas grandes, las mismas que oy mantiene, lampara grande de plata, calizes y todo genero de ôrnamentos dezentes para el culto diuino y menesterosos en la sachristia de dicha yglesia, con sus cajones para ellos, como tambien la ymmagen de el Santo Patriarcha que hauia costeado y puesto dicha Nouilisima Ciudad en el altar maior de dicha yglesia".

${ }^{26}$ Ibídem, f. 14v: "5.- Es condizion que por quanto consta por cauildo de onze de maio del año pasado de mil seiszientos ôchenta y dos, el orden de la Excelentisima Señora Doña Cathalina Antonia de Aragon Fernandez de Cordoba y Sandobal, duquesa de Segorbe, Cardona y Lerma, marquesa de Comares, my señora (que Santa Gloria aia) por la qual expresa Su Excelencia ser su voluntad y debozion que en el altar maior de la yglesia que auîa botado al ziudad labrar al señor San Francisco de Paula, se pusiese en medio vna ymmagen de Nuestra 
Aprovechando la erección de esta ermita, los mínimos decidieron fundar una comunidad de frailes en Lucena, no sin ciertas reticencias de las comunidades de religiosos de la ciudad. Con el apoyo del cabildo municipal, lograron establecerse primeramente como hospicio (1696) y finalmente como convento (1711). En la década de 1730, la comunidad de frailes al fin alcanzó la suficiente holgura económica como para poder emprender la construcción de una iglesia más capaz, aunque reutilizando la portada y el primer tramo de la antigua fábrica. También entonces se renovó el programa iconográfico de la capilla mayor, aprovechando la ejecución del nuevo retablo. Su hornacina central, a petición del regimiento municipal, quedaría a partir de entonces presidida por un grupo de talla de la Virgen de las Angustias, en tanto que las peanas laterales alojarían las imágenes de San José y San Joaquín, copatronos de la ciudad y devociones, asimismo, de los duques de Medinaceli ${ }^{27}$. También en aquel momento, y como había acordado el cabildo municipal décadas atrás, la capilla colateral del lado del evangelio fue entregada para enterramiento de los descendientes del ya citado don Gerónimo Gil Guerrero, cuyo mayorazgo había recaído en manos de la familia Valdecañas ${ }^{28}$. Fue en aquel momento cuando la imagen de San Francisco de Paula debió de ser

Señora de la Soledad y a los lados la del Santo Patriarcha [Francisco de Paula] y la del Vien Abenturado San Nicolas de Vari que auia embiado Su Excelencia, lo que en parte se cumplio, poniendose vna pintura de Maria Santisima de la Soledad que costeo Su Excelencia y aun permaneze en el dicho altar". De esta noticia da cuenta PALMA ROBLES, Luisfernando: "Una crónica del Seiscientos...", op. cit., pp. 311-313.

27 AHPCo, PN Lucena, Oficio de Francisco Tenllado Navarrete, 1734, leg. 2664P, f. 15r: "es seruido Su Excelencia [don Juan Francisco de la Cerda] adbertir â esta Muy Noble y Leal Ziudad será de su âgrado elija por sus compatronos a los gloriosisimos Señor San Joseph y San Joachin, por la expezial debozîon de Su Excelencia y de la dicha Excelentisima Señora doña Cathalina Antonia, su muger, mi señora, en cuia obserbanzia asi lo acordo; esta Ciudad solizita por este tan justo respecto, recordando su debozion y rebalidandola a los dichos gloriosos santos sus compatronos que sus santas ymmagenes se pongan asimismo en el altar maior â los lados de Maria Santisima de las Angustias". Sobre este particular, vid. PALMA ROBLES, Luisfernando: "San José y San Joaquín, copatronos de la ciudad de Lucena", San José Artesano (Lucena), s/n, 1995, pp. 4-7.

28 Archivo Histórico Municipal de Lucena, Caja 124, Actas Capitulares de 1738, ff. 520r- 521r: "En este cabildo se vieron dos memoriales que han presentado los señores D. Francisco Antonio de Angulo Valenzuela y Cisneros, D. Antonio Pablo de Valdecañas y Herrera, y D. José Antonio de Valdecañas Herrera y Guerrero, en que pretenden se les continúe la gracia y favor que hasta aquí han poseído de hacer sus entierros en la iglesia de San Francisco de Paula, de que esta ciudad es patrona, erigiendo túmulo dentro de su capilla mayor, como se ha practicado y practica con cualquiera de los caballeros capitulares, respecto de que por el año de ochenta y dos acordó esta ciudad consignarles a D. Francisco de las Cuevas y Velasco y D. Gerónimo Gil Guerrero dos capillas al lado del evangelio y epístola, en dicha iglesia, con los motivos que se tuvieron presentes en el/ ${ }^{520 r}$ citado acuerdo". Debo esta noticia a la gentileza de José Manuel Valle Porras. 
trasladada desde la vieja ermita al nuevo templo, colocándose en el retablo colateral que se construyó en esta capilla.

Tras la exclaustración, el templo de los mínimos serviría de sede a la parroquia de Santo Domingo de Guzmán, cuya iglesia se había hundido en 1866. Un año después, la escultura de San Francisco de Paula todavía continuaba en su capilla $^{29}$, pero finalmente terminaría pasando a una de las peanas del altar mayor $(\text { Figura } 4)^{30}$.

A pesar de que el recorrido del titular del convento se puede trazar con relativa certeza, no está claro que la imagen que nos ha llegado se corresponda con la tallada en 1686 por Pedro Roldán el Mozo. Su identificación resulta en extremo problemática, en primer lugar porque en la carta de pago no se indica si se trataba de una escultura de candelero - como la conservada- o por el contrario era de talla completa, lo que justificaría el alto precio pagado por ella. No hay que descartar que la escultura hubiera sido sustituida en el siglo XVIII por otra de vestir, aunque en todo caso la renovación hubo de realizarse antes de 1867 , cuando ya consta que la imagen poseía tres vestidos ${ }^{31}$.

De su examen estilístico tampoco se pueden extraer conclusiones claras. La efigie se adapta a la iconografía canónica del santo italiano, que porta en la diestra un escudo de plata con el lema de los mínimos, "CHARITAS", también reproducido en la diadema argéntea, mientras que en la otra mano porta el báculo. La talla de las manos presenta una factura correcta, aunque lógicamente el mayor empeño se concentra en la testa. Su rostro es severo, con los pómulos muy marcados, el ceño fruncido y la frente arrugada, rasgos que resultan tan apropiados para la representación de un santo ermitaño, mientras que la encarnadura mate y los ojos de cristal contribuyen a dotar de mayor vivacidad a la imagen (Figura 5). Es cierto que el uso del complemento vítreo no fue muy usado por el taller de Roldán -a diferencia de lo que ocurría en la escultura granadina contemporánea-, y también que el minucioso tallado de la barba -muy caligráfico- no se corresponde con las superficies abocetadas propias de la estética roldanesca ${ }^{32}$. Sin embargo,

${ }^{29}$ Inventario de 1867: "La hermosa imagen de San Francisco de Paula, de estatura natural, con tres vestidos. Uno de terciopelo negro bordado. Otro de terciopelo negro, con dos galones: uno ancho y otro angosto, de oro fino. Otro de veludillo negro, con galon basto dorado, que sirve de ordinario. Báculo de madera dorado, escudo de "Charitas" y diadema de metal dorado. Rosario de cuentas negras con engaste de plata”. PALMA ROBLES, Luisfernando: "San Francisco de Paula...", op. cit., pp. 30-31.

${ }^{30}$ En la actualidad su retablo sirve para alojar el titular de la cofradía de San José.

31 Ibídem.

${ }^{32}$ Quizás pudiera ser éste un grafismo de juventud de Roldán el Mozo -que por entonces apenas contaba con 21 años-, o una consecuencia de la intervención previa de Juan Caballero. Lo cierto es que la interpretación del santo dista bastante de la ofrecida por su padre en el retablo mayor de San Antonio de Cádiz (1679) y más aún de la versión que se ha atribuido a su hermana Luisa en la iglesia de la Victoria de Puerto Real (1687-1688). 
tampoco hay que perder de vista que fue precisamente en las décadas de $1680 \mathrm{y}$ 1690 cuando la plástica sevillana empezó a experimentar con las posibilidades expresivas de los ojos de cristal, cuyo uso alcanza su plenitud en la siguiente centuria. Además, la documentación nada aclara sobre el grado de intervención de Pedro Roldán en la obra, tan solo que estaba actuando sobre una escultura previamente comenzada por Juan Caballero ${ }^{33}$. El San Francisco de Paula de Lucena constituye, pues, una obra llena de interrogantes que, por el momento, no puede incluirse en el catálogo de Roldán el Mozo, pero que habrá que tener muy en cuenta en un futuro ante la eventual aparición de nuevas obras tempranas del escultor que permitan su definitiva confrontación.

De la presencia de Roldán el Mozo en Luque y Lucena a comienzos de 1686 pueden hacerse varias lecturas. Por un lado, su permanencia en la capital del Santo Reino puede estar relacionada con la dote de su esposa, que solo le fue entregada en el verano de 1686, dos años después del enlace. Pudiera ser que hasta entonces su suegro, Diego Romero, no hubiera logrado reunir el dinero (que, además, apenas alcanzó la cantidad de 1.161 reales, frente a los 5.500 que llevó el marido en $\left.\operatorname{arras}^{34}\right)$. Siguiendo esta hipótesis, el impago de la dote sería el motivo que retuvo al escultor en la ciudad, ocasión que aprovechó para hacerse con algunos trabajos de escultura.

Sin embargo, tampoco cabe descartar que el matrimonio hubiera permanecido en Jaén por propia voluntad. Desde luego, aunque se trataba de un foco artístico secundario, estaba lo suficientemente alejado del ámbito hispalense como para convertirse en el lugar idóneo donde iniciar una carrera profesional en solitario. De ser cierta -como creemos- esta segunda hipótesis, Roldán el Mozo se sumaría así a la diáspora de sus hermanos, quienes paulatinamente fueron alejándose del taller de Pedro Roldán durante la década de 1680. Sin duda, la localización de nuevas obras de Roldán el Mozo en Andalucía oriental arrojaría nueva luz sobre este asunto. Sea como fuere, lo cierto es que esta etapa giennense no se extendería por demasiado tiempo, pues a finales de esta década se encuentra de nuevo en Sevilla. Quizás el tardío otorgamiento de la dote marque la fecha de retorno de la pareja a la capital hispalense, que ante la inminente marcha, decidió dejar constancia notarial de la aportación de cada cuál al matrimonio.

Mayores similitudes encuentra, en cambio, con la imagen de San Pedro en cátedra que recientemente se ha identificado con la que contrató su padre en 1694 para Sanlúcar de Barrameda, y que acusa una indudable huella del taller. RODA PEÑA, José: Pedro Roldán..., op. cit., pp. 111 y 324-326; ALONSO DE LA SIERRA, Lorenzo y ESPINOSA DE LOS MONTEROS, Francisco, "Luisa Roldán. San Francisco de Paula", en ROMERO TORRES, José Luis y TORREJÓN DÍAZ, Antonio (coms.): Roldana..., op. cit., p. 192.

33 "Abiendo empezado a disponer dicha echura se ausento desta ciudad sin aberla acabado en la perfezion que rrequiere". Cfr. apéndice documental.

${ }^{34}$ GALIANO PUY, Rafael: "Las esculturas de la catedral...", op. cit., p. 127. 


\section{EL RETORNO A SEVILLA (1690-1699)}

Las últimas noticias que se tienen de Roldán el Mozo y su mujer en Jaén corresponden al verano de 1686, pero no se tiene constancia de su presencia en Sevilla hasta febrero de 1690, cuando contrata con su padre las veinticuatro columnas de jaspe para el templo hispalense del Buen Suceso. Este hecho probaría que a su regreso se reincorporó al obrador paterno, y de hecho cabe precisar que el matrimonio se instaló en la plazuela de Valderrama, donde se encontraba el taller y residían la mayoría de los roldanes. "Pedro Roldan, natural de Seuilla, casado, de veinte y siete años" y sin armas, figura viviendo en la mencionada plazuela en un alistamiento militar realizado al año siguiente por orden del rey, pues se preveía armar a la población ante un eventual ataque norteafricano ${ }^{35}$. En aquel enclave cohabitaba con sus padres y sus hermanas Isabel, Francisca y Ana, esposas respectivamente de Alejandro Martagón, José Felipe Duque Cornejo y José Fernández de Arteaga ${ }^{36}$. Estos dos últimos también fueron escultores, por lo que cabe imaginarlos integrados en el taller de su suegro, como también debía estarlo el joven Pedro Duque Cornejo, de apenas trece años.

Por aquel tiempo vendrían al mundo los tres hijos de Pedro Roldán el Mozo: Manuel, bautizado el 24 de enero de 1691 en la parroquia de San Juan de la Palma ${ }^{37}$; Tomás, que recibió las aguas el 14 de marzo de 1693 en la parroquia de San Marcos; y Fernando Juan, bautizado en esta última parroquia el 19 de marzo de $1696^{38}$. Al margen de estas noticias de carácter biográfico, poco más se sabe de su actividad como escultor durante estos años, en los que seguramente debió colaborar en los encargos asumidos por el taller de su padre, como las esculturas del retablo mayor del convento hispalense de Santa María de Jesús (1690), el San

${ }_{35}$ AMSe (Archivo Municipal de Sevilla), Sección IV, Escribanías del Cabildo siglo XVII, tomo 27, parroquias de Santa Catalina y San Marcos, f. 98r. Doc. cit. en TORREJÓN DÍAZ, Antonio: "El entorno familiar...", op. cit., p. 75, n. 23.

${ }^{36}$ Ibídem, f. 98r: "Alejandro Martagon, natural de Seuilla, casado, de hedad de treintta y un años y no tiene armas - I [...] Joseph Cornejo, natural de Seuilla, casado, de hedad de treintta y ocho años y no tiene armas — I [...] Don Joseph de Quiñones Artiaga, natural de Seuilla, casado, de hedad de quarentta años y no tiene armas_l'" ". El viejo Pedro Roldán no aparece en este alistamiento, ya que solo quedaron registrados los hombres entre 18 y 60 años, y él rondaba los 67.

37 SANCHO CORBACHO, Heliodoro: El escultor sevillano..., op. cit., pp. 34-35.

${ }^{38}$ GÓMEZ Y ACEVES, Antonio: "Estudios necrológicos. Pedro Roldan el Viejo, su esposa e hijos", Gaceta de Madrid, 4526, 4 de febrero de 1847, p. 3. Este artículo de prensa había pasado totalmente desapercibido hasta que repararon en él ESPINOSA DE LOS MONTEROS SÁNCHEZ, Francisco y PATRÓN SANDOVAL, Juan Antonio: "Nuevos datos biográficos sobre Pedro Roldán y su taller". Boletín de las cofradías de Sevilla, 587, enero 2008, pp. 68-71. 
Pedro en cátedra para Sanlúcar de Barrameda (1694) o el ciclo pétreo del convento dominico de San Pablo (1694-1696) ${ }^{39}$.

La siguiente referencia documental del joven Pedro Roldán lo sitúa en Archidona (Málaga). Hasta esta villa se había desplazado el 20 de septiembre de 1697 para concertar con la hermandad de Jesús Nazareno la ejecución del retablo mayor de su ermita ${ }^{40}$. Aunque se ha supuesto que el otorgante fue Roldán el Viejo, no parece lógico que con 73 años emprendiera un viaje de varios días en calesa para contratar una obra menor ${ }^{41}$. Además, el análisis de la firma deja poco margen de dudas: en la comparativa que aportamos pueden cotejarse hasta seis firmas diferentes de Pedro Roldán el Mozo, en un rango cronológico comprendido entre 1686 y 1717, que demuestran que el escultor presente en Archidona fue él (Figura 6) ${ }^{42}$. En todas sus firmas puede advertirse como rasgo característico la utilización de la doble erre para escribir el apellido "Roldán", siempre en minúscula y yuxtapuesto al nombre; también puede observarse que solía firmar pero no rubricar. La escasa soltura a la hora de escribir constituye un rasgo de analfabetismo, propia de quien firma de memoria por no saber leer, lo que explicaría por qué a veces invierte el orden de las letras, escribiendo "Pdero" en lugar de "Pedro"43.

El contrato de este retablo resulta relevante por cuanto supone el testimonio más antiguo de la actividad de Roldán el Mozo como retablista. A diferencia de otros trabajos en que sólo actúa como ejecutor material del retablo, aquí

${ }^{39}$ RODA PEÑA, José: Pedro Roldán..., pp. 118-122.

40 GARRIDO PÉREZ, Manuel: "Pedro Roldán en Archidona: Documentación sobre un retablo desaparecido", Cuadernos de Arte de la Universidad de Granada, 41, 2010, pp. 321-332.

${ }^{41}$ Distinto es el caso del retablo de la parroquia de Santa Bárbara, en Écija, contratado un año antes por Pedro Roldán el Viejo y Cristóbal de Guadix. En este caso sí consta que el maestro se desplazó para su contrata, pero hay que tener en cuenta que se trataba de una población más cercana y de una obra de mayor envergadura, concertada en 24.000 reales, precio casi cinco veces mayor que el del retablo de Archidona. VILLA NOGALES, Fernando y MIRA CABALLOS, Esteban: Documentos inéditos para la Historia del Arte en la provincia de Sevilla (siglos XVI al XVIII). Sevilla, 1993, pp. 122-124.

${ }^{42}$ Las firmas están tomadas de las siguientes fuentes: (1) Contrato de escultura del retablo mayor de Luque, 1686-I-16; (2) Carta de pago del San Francisco de Paula de Lucena, 1686-II-28; (3) Contrato del retablo de Jesús Nazareno de Archidona, 1697-IX-20; (4) Partición de bienes de Pedro Roldán el Viejo, 1700-XII-1; (5) Contrato del retablo mayor de Calañas, 1712-IV-23; (6) Recibo de 50 reales por la obra del retablo de Trigueros, 1717-IX14. Las firmas 2 y 6 proceden de fotografías tomadas por el autor; el resto han sido publicadas por LUQUE CARRILLO, Juan: "El retablo de Luque...", op. cit.; GARRIDO PÉREZ, Manuel. "Pedro Roldán en Archidona...”, op. cit., y CARO QUESADA, Ma Salud: Noticias de escultura..., op. cit., p. 163.

${ }_{43}$ Así ocurre en la firma que estampa en la escritura de partición de bienes de su padre (1700) y en la que aparece en un recibo otorgado para la obra de Trigueros (1717), donde por haber emborronado parte del nombre continuó escribiéndolo en la línea inferior. 
sentencia que él había sido el autor intelectual de la traza ("segun la planta que e echo"), aunque en cualquier caso tuvo que tratarse de una obra de poca entidad, teniendo en cuenta que se ajustó por apenas 5.000 reales y que en 1753 sería sustituida por un nuevo retablo. Lamentablemente la escritura de obligación resulta bastante parca en detalles, lo que nos impide hacernos una idea de algo tan elemental como el tipo de soportes utilizados. Sí conviene mencionar que en ella actuó como fiador Francisco Roldán Estudillo y Conejo, un primo lejano que vivía en Archidona ${ }^{44}$, quien bien pudo servir de enlace entre los promotores y el artista.

\section{TRABAJOS TRAS LA MUERTE DE PEDRO ROLDÁN EL VIEJO (1700-1720)}

A comienzos de agosto de 1699 moría Pedro Roldán el Viejo. Se ha señalado que su desaparición precipitaría la disolución del obrador familiar, aunque ya se ha visto cómo desde años atrás algunos de sus componentes venían contratando obras en solitario. Dejando a un lado el caso excepcional de Luisa Roldán y Luis Antonio de los Arcos -afincados en la Corte-, para entonces Marcelino Roldán, María Roldán y su esposo Matías de Brunenque contaban con más de una década de actividad independiente; por ejemplo, casi al mismo tiempo que Roldán el Mozo se encargaba del retablo del Nazareno para Archidona, estos últimos realizaban la Virgen de las Nieves de la colegiata de Olivares (1697) ${ }^{45}$, mientras que un año después Marcelino tallaría cuatro ángeles lampareros para la cofradía sevillana de la Virgen de la Soledad ${ }^{46}$. Por lo que respecta a José Felipe Duque Cornejo, en 1696 había tallado la Virgen de los Dolores de Carmona -su primera obra conocida, encarnada por su esposa Francisca-, y a comienzos de 1699 (meses antes del fallecimiento de Pedro Roldán) él y su hijo ya habían acordado con el retablista Juan del Castillo ocuparse del apartado escultórico del retablo de la Virgen de la Soledad que este último iba a construir para la iglesia de la Mota en Marchena ${ }^{47}$.

${ }^{44}$ De nuevo nos encontramos ante un problema de homonimia, pues por aquel tiempo existieron dos Francisco Roldán Estudillo y Conejo, tío y sobrino, respectivamente primo segundo e hijo de primo segundo de Pedro Roldán el Mozo. El tío fue presbítero y parece que estuvo avecindado durante un tiempo en Córdoba; el sobrino había casado en 1694 con Antonia Jacinta Rojano. Cfr. SANCHO CORBACHO, Heliodoro: El escultor sevillano..., pp. 68 y 75. Véase también el árbol genealógico incluido en este libro.

45 AMORES MARTÍNEZ, Francisco: La Colegiata de Olivares, Sevilla, 2001, p. 42.

46 CAÑIZARES JAPÓN, Ramón y PASTOR TORRES, Álvaro: "Nuevas obras de Pedro y Marcelino Roldán para la Capilla de la Soledad en el Convento del Carmen”, Boletín de las Cofradias de Sevilla, 576, 2007, pp. 111-113.

${ }^{47}$ Este retablo es el mismo por el que José Felipe Duque Cornejo otorga carta de pago en 1704. Cfr. GARCÍA LUQUE, Manuel: "Pedro Duque Cornejo y la escultura barroca 
Ahora bien, la actividad independiente de estos maestros tampoco puede interpretarse como un signo inequívoco de su total emancipación del taller de Pedro Roldán, con el que pudieron seguir colaborando o incluso compartir espacio físico dentro del mismo obrador ${ }^{48}$. Son incógnitas que, por desgracia, ni la documentación ni las obras terminan de aclarar, aunque resulta interesante constatar cómo en 1705, a los seis años de su muerte, buena parte de la familia aún continuaba viviendo en la plazuela de Valderrama, donde -recordemos-se encontraba el antiguo obrador. En realidad, la situación no había cambiado mucho respecto a la radiografía que nos ofrece el alistamiento de 1691: en aquel enclave mantenían su residencia las hermanas Francisca y Ana Roldán, mujeres -como ya se dijo- de José Felipe Duque Cornejo y José Fernández de Arteaga ${ }^{49}$. Junto a ellas aparece su hermana Teresa, casada en segundas nupcias con el escultor Pedro Castillejos, y, como novedad, también se registra la presencia del primogénito, Marcelino, que había casado en segundas nupcias con Josefa de Serrallonga. Teniendo en cuenta que el enlace tuvo lugar en 1698 en la vecina parroquia de San Marcos, es probable que el matrimonio se instalara desde aquel momento en la plazuela de Valderrama y, si no fue así, tuvieron que hacerlo tras la muerte del padre, pues Marcelino había heredado la vivienda principal, donde continuaba viviendo su madre, Teresa de Villavicencio. Es posible que algunos de estos artistas siguieran trabajando juntos tras la muerte del viejo Roldán, como Pedro Castillejos y José Fernández de Arteaga, que bien pudieron integrarse como oficiales del taller de los Duque Cornejo ${ }^{50}$.

El que sí aparece totalmente emancipado es Pedro Roldán el Mozo, que para entonces ya no vivía en la plazuela de Valderrama, sino en sus inmediaciones (Calle Real $)^{51}$. En enero de 1700 contrata junto al retablista Pedro García de Acuña

en Sevilla: nuevas aportaciones", Cuadernos de Arte de la Universidad de Granada, 44, 2013, p. 80, n. 4.

${ }^{48}$ La práctica de compartir obrador entre diferentes maestros no era algo ni mucho menos inédito en el ámbito hispalense, como demuestra el caso de los hermanos doradores Borja Machado, con taller en la calle Colcheros, o el de los maestros pintores Diego García de Castro y Tomás Contreras, en la plazuela de San Pablo. GARCÍA BAEZA, Antonio: Entre el obrador y la academia. La enseñanza de las artes en Sevilla durante la segunda mitad del Seiscientos. Sevilla, 2014, pp. 48-49.

49 Aunque en el padrón se le cita como "Antonio Fernandez de Arteaga", debe tratarse de un errata.

${ }^{50}$ Así lo intuye TORREJÓN DÍAZ, Antonio: “El entorno artístico...”, op. cit., p. 68. Los datos del padrón, utilizados por este mismo autor, se encuentran en AMSe, Escribanía 2. a del Cabildo, s. XVIII, t. 261, Padrón de 1705, nº 13 San Marcos.

${ }^{51}$ En 1703 recibe en arrendamiento una casa del Hospital del Amor de Dios, situada en la Calle Real, y en 1707 recibe en arrendamiento otra casa perteneciente al convento del Socorro en la calle Ancha de San Marcos. CARO QUESADA, Ma Salud: Noticias de escultura..., op. cit., pp. 163-164. 
el retablo de la capilla de Jesús Nazareno en la iglesia del convento de la Victoria de Osuna. Es sintomático que a partir de este momento comience a recibir el tratamiento de "don". Por este trabajo recibiría 3.250 reales, precio ciertamente ajustado aun contando con que la madera le sería entregada, ya aparejada por García de Acuña ${ }^{52}$.

El apartado escultórico está formado por cuatro altorrelieves pasionistas, un relieve del paño de la Verónica, más las figuras de bulto del Calvario, el Resucitado y cuatro ángeles. Las mejores piezas de todo el grupo son el Crucificado y el Resucitado, que muestran un modelado anatómico blando aunque correcto, con el habitual tratamiento abocetado en cabellos y paños propio de los seguidores de Pedro Roldán. Mucho más mediocres son las figuras secundarias del Calvario y, sobre todo, los ángeles, que presentan un plegado de paños muy artificioso pero poco verosímil. Los grandes relieves tampoco resultan de gran calidad pero ofrecen el interés de estar inspirados en el ciclo pictórico pasionista que cubre los muros de la capilla, reelaboración a su vez de las famosas estampas de Hieronymus Wierix que ilustran las Historias Evangélicas del Padre Nadal. Este descenso del nivel cualitativo no se puede achacar a la distancia a la que estaba prevista contemplar las obras, pues es una cuestión que afecta por igual a los relieves de los pisos alto y bajo. Por ejemplo, en la historia de la Entrada en Jerusalén (Figura 7), el escultor ha logrado infundir la sensación de multitud con la aglomeración de cabezas en el reducido marco arquitectónico, pero la falta de proporción en los personajes resulta manifiesta, sobre todo en las cabezas de los niños. Ni siquiera la correcta policromía, aplicada en 1714 por Lorenzo Vallejo, consigue ocultar su mediocre manufactura ${ }^{53}$.

No se conserva ninguna otra obra segura más allá de este ejemplo, aunque los documentos apuntan que su actividad continuó ligada al mundo del retablo: en 1704 se asocia con el ensamblador Antonio de Carvajal para ejecutar el retablo de la hermandad sacramental de la parroquia sevillana de Santiago (no conservado) $^{54}$ y en 1706 se ocupa del apartado escultórico del retablo mayor de la parroquia de Galaroza (Huelva), realizado por los retablistas portugueses Manuel Pinto y Custodio Álvarez. A Roldán corresponderían las imágenes de San Juan y la Dolorosa (para formar un calvario con un Crucificado preexistente), San José, seis ángeles y cuatro serafines, esculturas todas ellas que serían quemadas junto al retablo en la Guerra Civil ${ }^{55}$.

${ }^{52}$ MORENO ORTEGA, Rosario: "El retablo de Jesús Nazareno de Osuna. Aportación a la obra de Pedro Roldán 'el Mozo'”, Archivo Hispalense, 222, 1990, pp. 191-197.

53 Ibídem, p. 194.

${ }^{54}$ CARO QUESADA, M Malud: Noticias de escultura..., p. 164.

${ }^{55}$ RODRÍGUEZ BENEYTO, Emilio: Aspectos históricos de Galaroza. Sevilla, 1986, p. 112. Lo identifica erróneamente con el nieto de Roldán, como también PLEGUEZUELO HERNÁNDEZ, Alfonso: "Una colaboración entre artistas portugueses y 
Se da el caso de que los dos siguientes trabajos documentados también fueron realizados para la provincia de Huelva y perecieron en idénticas circunstancias, lo que supone un escollo fundamental para estudiar la obra de Roldán el Mozo. En abril de 1712 contrataba en solitario el retablo mayor de la iglesia parroquial de Calañas, un encargo de envergadura, a realizar en madera de castaño ${ }^{56}$, por el que percibiría la suma de 1.450 ducados (aproximadamente 16.000 reales) (Figura 8) ${ }^{57}$.

A diferencia del retablo para Archidona, en esta ocasión no está claro que Roldán fuera el autor de traza, pues aunque se le denomina "maestro arquitecto", fue uno de los varios artistas que hicieron postura sobre un proyecto al parecer ya dado por la autoridad eclesiástica ${ }^{58}$. Su esquema, tetrástilo y salomónico, repetía los diseños habituales del retablo sevillano del último tercio del Seiscientos, algo que resulta hasta cierto punto lógico para este momento, teniendo en cuenta que la nueva modalidad retablística introducida por Jerónimo Balbás -basada en el estípite y la hoja de cardo- todavía tardaría algunos años en ser asumida por los artífices locales. La única aportación al diseño que con certeza se puede atribuir a Roldán el Mozo son los cuatro ángeles tenantes que soportan las columnas salomónicas, que introdujo en sustitución de las cabezas de serafínes. Aparte de estas figuras angélicas, el apartado escultórico quedaba limitado a las esculturas de San Pedro y San Pablo de las hornacinas y el relieve del Buen Pastor de la portezuela del sagrario, ya que el Calvario del ático quedaría configurado por imágenes de acarreo. Por lo poco que se puede advertir en una fotografía en blanco y negro, las figuras de los apóstoles acusaban una fuerte impronta roldanesca, ofreciendo actitudes serenas y contenidas que poco tenían que ver ya con el carácter violento y movido del Apostolado que contemporáneamente estaba realizando su sobrino Duque Cornejo para la parroquia granadina de la Virgen de las Angustias ${ }^{59}$. Es

andaluces: la decoración de la iglesia de Galaroza (Huelva)", en Patrimonio histórico-artístico en la provincia de Huelva: ponencias de las III Jornadas de Patrimonio de la Sierra de Huelva (Aroche, 1988). Huelva, 1989, p. 4. Vuelve a sorprender el escaso dinero recibido por su trabajo, apenas 950 reales. Se conserva una fotografía del retablo, publicada por el autor, pero por desgracia las esculturas de Roldán aparecen demasiado desdibujadas como poder abordar su análisis.

${ }^{56}$ El empleo de esta madera se ha interpretado como una forma de recortar gastos, dada la cercanía de la villa a la Sierra de Aracena, donde abunda esta especie. HERRERA GARCÍA, Francisco Javier: El retablo sevillano en la primera mitad del siglo XVIII: evolución y difusión del retablo de estípites, Sevilla, 2001, p. 208.

${ }^{57}$ CARO QUESADA, M Malud: Noticias de escultura..., op. cit., pp. 164-166. Se constituye como su fiador Juan Rayo, tirador de oro, cuya presencia sólo cabe ser interpretada como mera garantía jurídica.

${ }^{58}$ Sobre el diseño tan solo se señala que "esta en dichos autos rubricado del ynfraescripto notario".

${ }^{59}$ GILA MEDINA, Lázaro: "El Apostolado, el Salvador y la Virgen de la parroquiabasílica de Nuestra Señora de las Angustias de Granada, obra de Duque Cornejo, a la luz de 
probable que el banco y el primer cuerpo de este retablo estuvieran terminados para enero de 1714, cuando Pedro Roldán otorga carta de pago ${ }^{60}$. Por razones que se ignoran, la obra quedó detenida hasta julio de 1717, cuando el escultor traspasa al ensamblador Pedro Guisado la terminación del ático ${ }^{61}$.

Prácticamente al mismo tiempo que Roldán el Mozo desiste del encargo de Calañas, se hace cargo de otro retablo que también había quedado inconcluso: el de la iglesia parroquial de San Antón, en Trigueros (Huelva). La tormentosa historia de este altar se remonta a 1713, cuando el ensamblador trianero Miguel Franco y el escultor Pedro Duque Cornejo lo contratan a la baja por 18.000 reales $^{62}$. Dos años más tarde, viendo que el dinero se había consumido y que el retablo aún no veía su fin, el principal obligado -Miguel Franco- traspasó su obligación al fiador, Duque Cornejo, quien para entonces tampoco había logrado entregar las esculturas correspondientes. El 1 de septiembre de 1716, Cornejo lamentaba su dificultad para concluir su trabajo, ya que se encontraba perseguido por la justicia y se había refugiado en el noviciado jesuítico de San Luis de los Franceses, aunque declaraba su firme voluntad de acabar su parte, pues si "no es yo no puede trabajar otro en ello". La realidad fue bien distinta, pues a las pocas semanas el escultor puso rumbo a Granada, donde encontró resguardo hasta 1719. Esta "fuga" de Cornejo precipitó los acontecimientos, pues el vicario de Trigueros, impacientado, volvió a recurrir a Miguel Franco, que se encontraba en Bonares, logrando su arresto y el embargo de sus bienes ${ }^{63}$.

La solución a todo este entuerto la puso Pedro Roldán el Mozo, quien en septiembre de 1717 se hizo cargo del remate de la obra de escultura. Aunque Franco y Cornejo habían consumido todo el dinero previsto en el contrato, el vicario triguerense aceptó dar otros 200 reales a Roldán como "ayuda de costa”. El escultor se encargaría de terminar las esculturas de San Fernando, San Ginés, algunos ángeles y otros adornos, que probablemente había dejado su sobrino a medio

la documentación", en Pulchrum: Scripta varia in honorem María Concepción García Gaínza, Pamplona, 2011, pp. 357-365; GARCÍA LUQUE, Manuel: "Un conjunto singular del barroco sevillano en Granada: el Apostolado de la basílica de las Angustias, obra de Pedro Duque Cornejo", Cuadernos de Arte de la Universidad de Granada, 41, 2010, pp. 169-188.

${ }^{60} \mathrm{Se}$ trataba de un pago a cuenta, pues tan solo se le abonaron 2.000 reales. En el contrato se había estipulado que recibiría el dinero en tres pagas: un tercio al inicio, un tercio cuando terminara el banco y el primer cuerpo y el tercio último al fin de la obra. SANCHO CORBACHO, Heliodoro: Arquitectura sevillana del siglo XVIII. Sevilla, 1934, p. 54.

${ }^{61}$ Ibídem, pp. 54-55. Pedro Roldán el Mozo dio carta final de pago en 24 de diciembre de aquel año.

${ }^{62}$ Los informes de los retablistas Juan de Valencia y Antonio de Carvajal apuntaban a que la obra no podía hacerse por menos de 21.000-22.000 reales.

${ }^{63}$ CARRASCO TERRIZA, Manuel: "El retablo mayor de Trigueros, obra de Miguel Franco, Duque Cornejo y Pedro Roldán (I)”, Boletín Oficial del Obispado de Huelva, 254, 1985, p. 117-124. 
terminar antes de marchar a Granada. El grado de intervención de uno y otro resulta imposible de valorar, toda vez que la mayor parte del retablo pereció en el incendio de 1936.

El socorro dispensado por Roldán el Mozo a su sobrino constituye la mejor prueba de la buena sintonía existente entre ellos. No en balde, él había actuado como testigo en el enlace matrimonial de Duque Cornejo con Isabel de Arteaga ${ }^{64}$, y también acabó mudándose a la calle Beatos ${ }^{65}$, donde precisamente vivía su sobrino. Aunque se ha afirmado que por estos años Pedro Roldán llegó a avecindarse en la gaditana villa de Espera ${ }^{66}$, hemos advertido que de nuevo se trata de una confusión por homonimia: el Pedro Roldán que en 1718 arrienda una almona de jabón al duque de Medinaceli nada tiene ver con el escultor, como acredita el cotejo de su firma y el hecho de que en 1726 revalidara el compromiso de arrendamiento ${ }^{67}$. Para entonces el escultor ya llevaba seis años muerto, pues había fallecido relativamente joven -con cerca de 55 años-, recibiendo sepultura el 3 de mayo de 1720 en la parroquia de San Marcos de Sevilla ${ }^{68}$.

\section{APÉNDICE DOCUMENTAL}

Carta de pago de Pedro Roldán el Mozo por una imagen de San Francisco de Paula para don Gerónimo Gil Guerrero

1686, febrero, 28. Lucena

AHPCo, PN de Lucena, Oficio de Francisco Espinosa de Velasco, 1686, leg. 2846P, f. 21 r-v.

Al margen: "Bartolome Ramirez y Juan Nabajas, carta de pago y lasto contra don Geronimo Jil Guerrero y Pedro Roldan"

En la ciudad de Luzena, en veinte y ocho dias del mes de febrero de mill seiszientos y ochenta y seis años, ante mi, el puvlico scribano publico y testigos ynfraescriptos, parezieron don Geronimo Gil Guerrero, alguazil maior desta

${ }^{64}$ SANCHO CORBACHO, Heliodoro: El escultor sevillano..., op. cit., p. 36.

${ }^{65}$ En 1712 Pedro Roldán pone en arrendamiento una casa en esta misma calle (SANCHO CORBACHO, Heliodoro: El escultor sevillano..., op. cit., p. 103), probablemente la misma en la que luego vivirá en 1714, pues en el cuaderno de memorias de los gremios aparece citado como residente "en calle Beatos / Collazion de San Julian". AMSe, Sec. V, Escribanía del Cabildo siglo XVIII, tomo 6, doc. 17, f. 60r. Doc. cit. en TORREJÓN DÍAZ, Antonio: "El entorno familiar...", op. cit., p. 72.

${ }^{66}$ CARO QUESADA, M ${ }^{\mathrm{a}}$ Salud: Noticias de escultura..., op. cit., p. 167.

${ }^{67}$ Archivo Histórico Provincial de Sevilla, Protocolos Notariales de Sevilla, Oficio 19, 1726, leg. 13105, f. 693r (1726-VI-3).

${ }^{68}$ GÓMEZ Y ACEVES, Antonio: "Estudios necrológicos...”, op. cit., p. 3; ESPINOSA DE LOS MONTEROS SÁNCHEZ, Francisco y PATRÓN SANDOVAL, Juan Antonio: "Nuevos datos biográficos...", op. cit., p. 71. 
ziudad, rrejidor y comisario de la obra y hermita de mi padre San Francisco de Paula que se esta fabricando en esta ziudad, de la una parte, y de la otra Pedro Roldan, maestro de scultura, vezino de la ziudad de Jaen y rresidente en esta ziudad, y Bartolome Ramirez y Juan Nabajas, vecinos desta ziudad, como fiadores de mancomun de Juan Caballero, maestro scultor en la obra que sera declarada. Y dijeron que por quanto el dicho Juan Caballero y los susodichos se obligaron a haçer una hechura de mi padre San Francisco de Paula de scultoria [sic] acabada y puesta en toda perfezion y a satisfazion de maestros del dicho arte, y es asi que el dicho Juan Caballero abiendo empezado a disponer dicha echura se ausento desta ciudad sin aberla acabado en la perfezion que rrequiere el dicho don Geronimo Gil Guerrero, como fiadores del susodicho les obligo a que buscasen persona y maestro del dicho arte que cumpliese con dicha obligazion, los quales conduzieron a esta ziudad al dicho Pedro Roldan para que acabase dicha echura en toda perfeczion, el qual lo a echo asi y entregado al dicho don Geronimo Gil Guerrero a su satisfazion y de maestros que de ello entienden, para cuio trabajo y manifactura el dicho don Geronimo Gil Guerrero a pagado la cantidad en que estaba conzertada dicha echura y ymajen y demas de ella a dado zinquenta reales al dicho Pedro Roldan, y los dichos Bartolome Ramirez y Juan Nabajas, como fiadores del dicho Juan Caballero le an pagado ziento y cinquenta rreales por aberles sacado de la obligazion que tenian echa con el dicho Juan Caballero con calidad de que les a de otorgar carta de pago, zesion y lasto contra la persona y bienes del dicho obligado principal por razón de no auer cumplido con su obligazion, y de acuerdo, conformidad de todas las partes mencionados, dicho don Geronimo Gil Guerrero, como tal comisario de dicha obra, se dio por contento y entregado de dicha hechura/21r de scultoria [sic] de mi padre San Francisco de Paula por tenerla en su poder y en su satisfazion y de maestros que de ello entienden y se dio por entregado a su boluntad y por libres al dicho Juan Caballero y a sus fiadores para no les pedir ni rrepetir por razón de lo rreferido cosa alguna, en ningun tienpo, y el dicho Pedro Roldan confeso aber rreziuido de dicho don Geronimo Gil Guerrero nuebezientos rreales que es la cantidad en que dicho Juan Caballero tenia conzertada la dicha echura y demas de ella los çinquenta reales por rrazon de auerla acabado y puesta en perfeczion como estaba obligado el dicho Juan Caballero, y de los dichos Bartolome Ramires y Juan Nabajas, sus fiadores, ziento y cinquenta reales, moneda de vellon, que por redimir su bejazion y sacarles a paz y a salbo de ella le an pagado y satisfecho, según lo trataron y comunicaron, de cuia cantidad, por aberla rreziuido, asi del dicho don Geronimo Jil Guerrero, como ba declarado, como de los dichos fiadores del dicho Juan Caballero, se dio por contento y entregado a su boluntad y rrenunzio las leies de la no numerata pecunia, prueba del entrego y rrezibo como en ella se contiene y les otorgo a los dichos fiadores tan bastante carta de pago, finiquito, zesion y lasto de los dichos ziento y cinquenta reales para que los puedan aber, rrezibir y cobrar judicial o estrajudizialmente del dicho Juan Caballero y de sus bienes, por razón de 
no aber cumplido con dicha obligazion, para lo qual parezcan ante qualesquier juezes y justizias destos rreinos y señoríos y presenten esta escriptura y hagan todos los autos y dilixencias que a su derecho combengan, y asi lo otorgaron todas las dichas partes y lo firmaron de sus nombres, siendo testigos Juan de Godoy y Francisco Ximenez y Joseph Geronimo Spinosa, vezinos de Luzena, y doy fee conozco a dichos otorgantes.

Don Geronimo Gil Guerrero [firmado y rubricado]

+Pedro Rroldan [firmado y rubricado]

Juan Nabajas [firmado y rubricado]

Bartolome Ramirez [firmado y rubricado]

Ante mi, Francisco Spinosa, scribano [firmado y rubricado] ${ }^{21 v}$

Fecha de recepción: 30 de septiembre de 2015.

Fecha de aceptación: 20 de noviembre de 2015. 


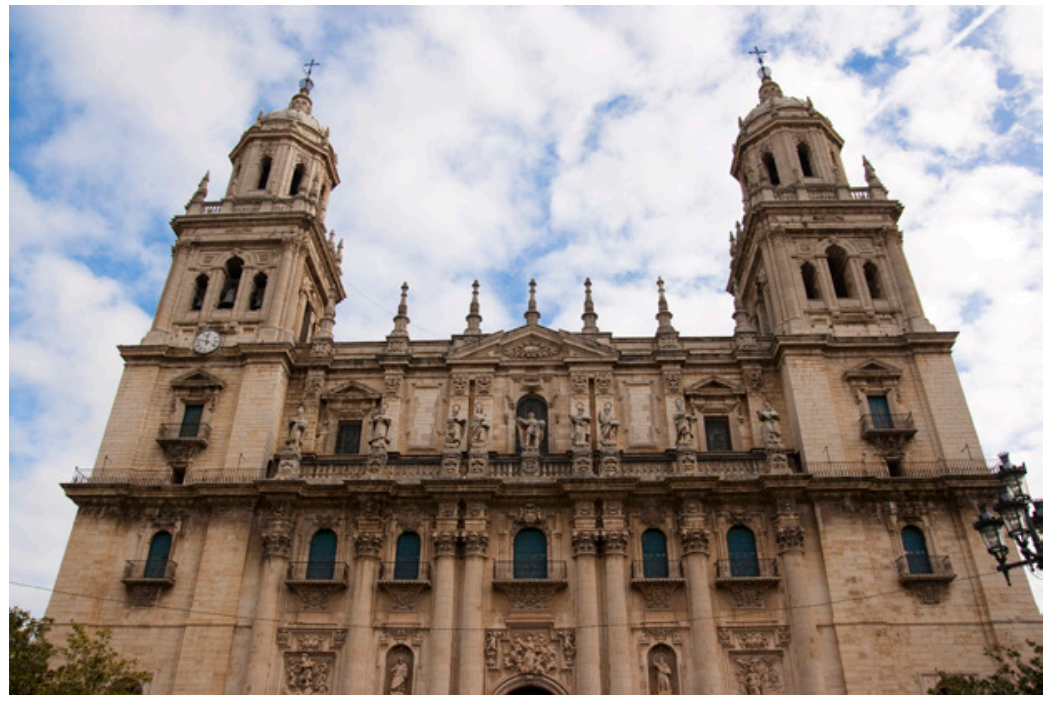

Figura 1. Fachada de la catedral, Eufrasio López de Rojas y otros, Jaén.

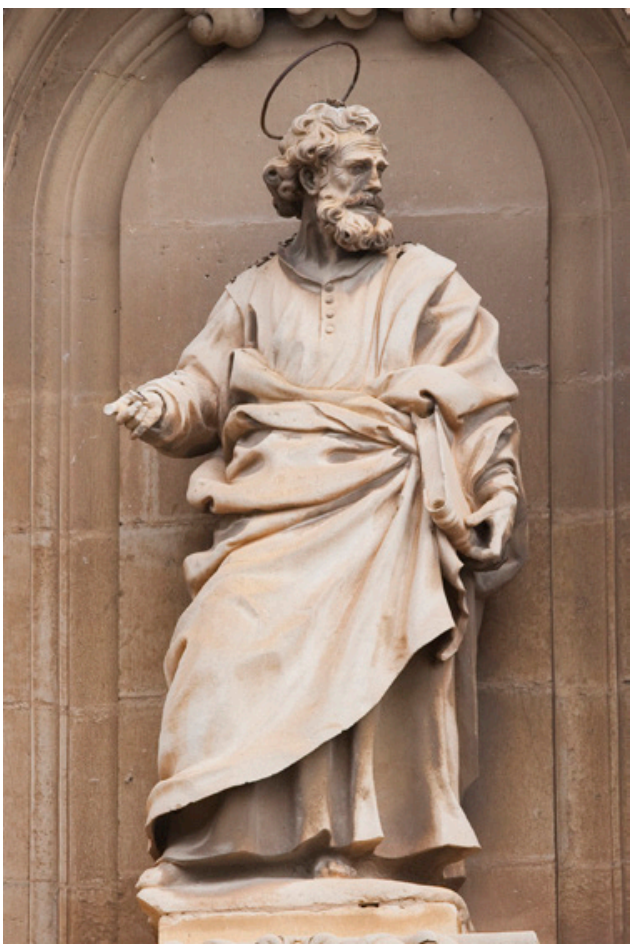

Figura 2. San Pedro, Pedro Roldán el Viejo, 1677, Jaén, catedral. 


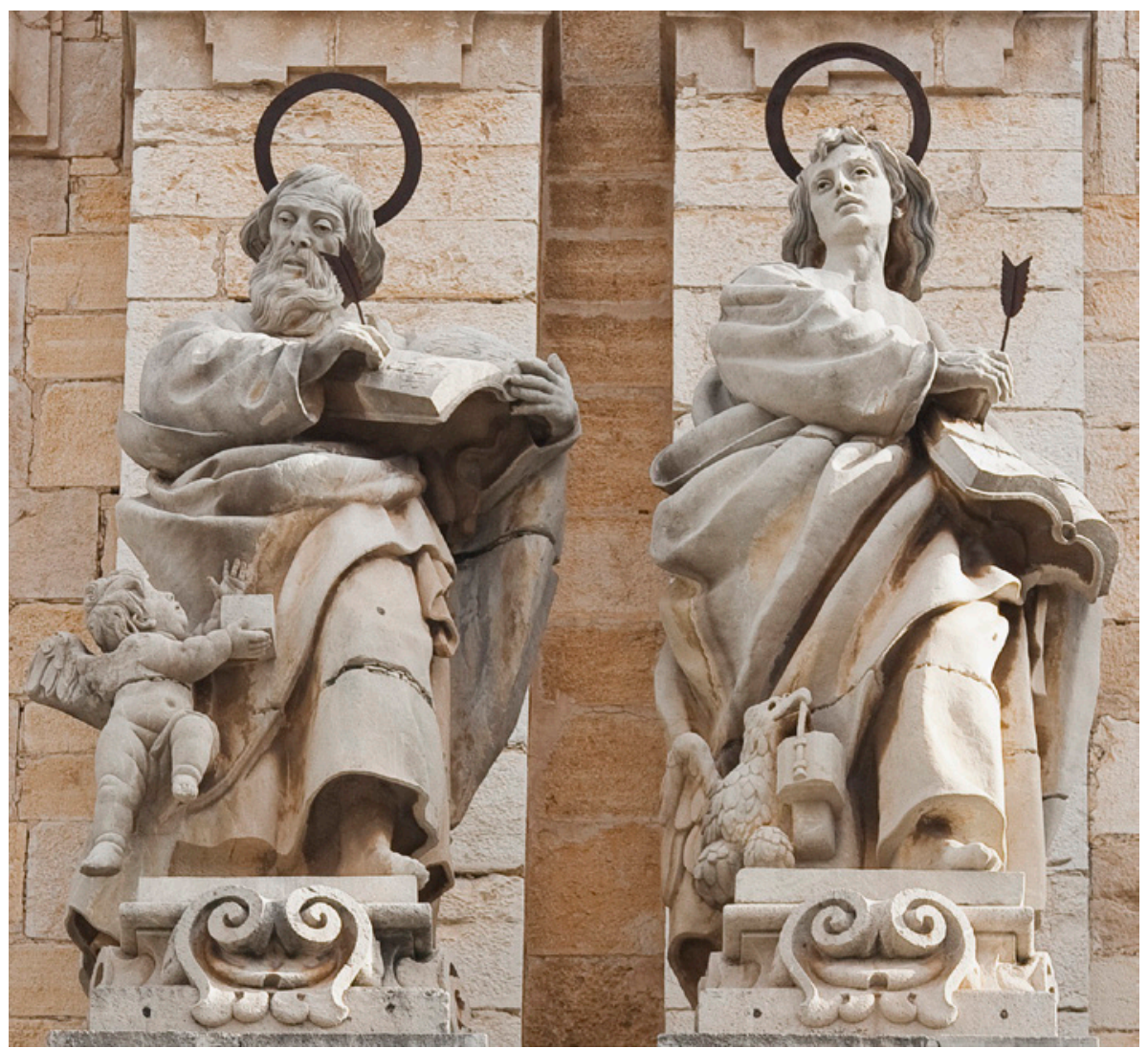

Figuras 3. San Mateo y San Juan, Pedro Roldán el Viejo y ¿Pedro Roldán el Mozo?, 1683-1684, Jaén, catedral. 


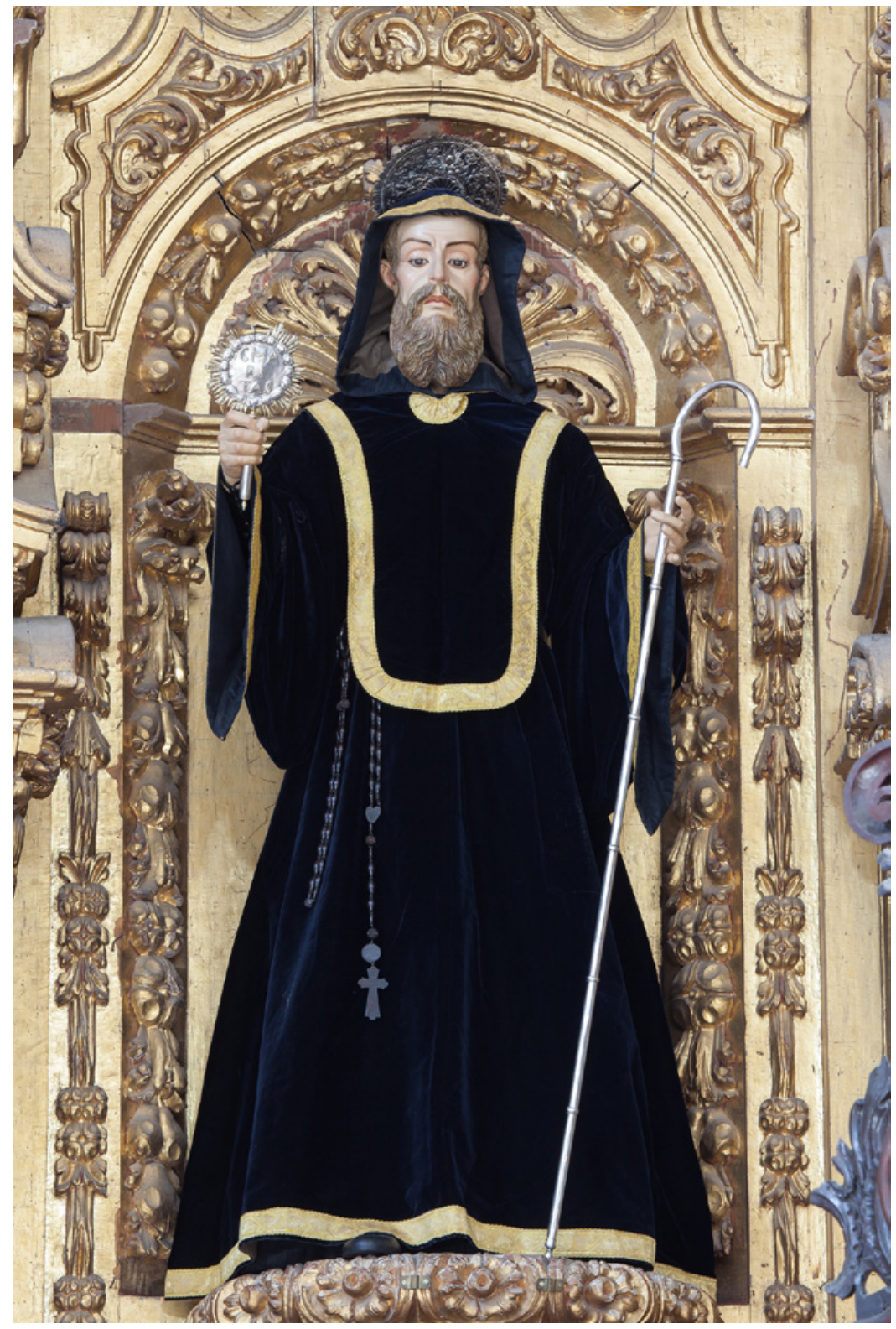

Figura 4. San Francisco de Paula, ¿Pedro Roldán el Mozo y Juan Caballero? Lucena, iglesia parroquial de Santo Domingo. 


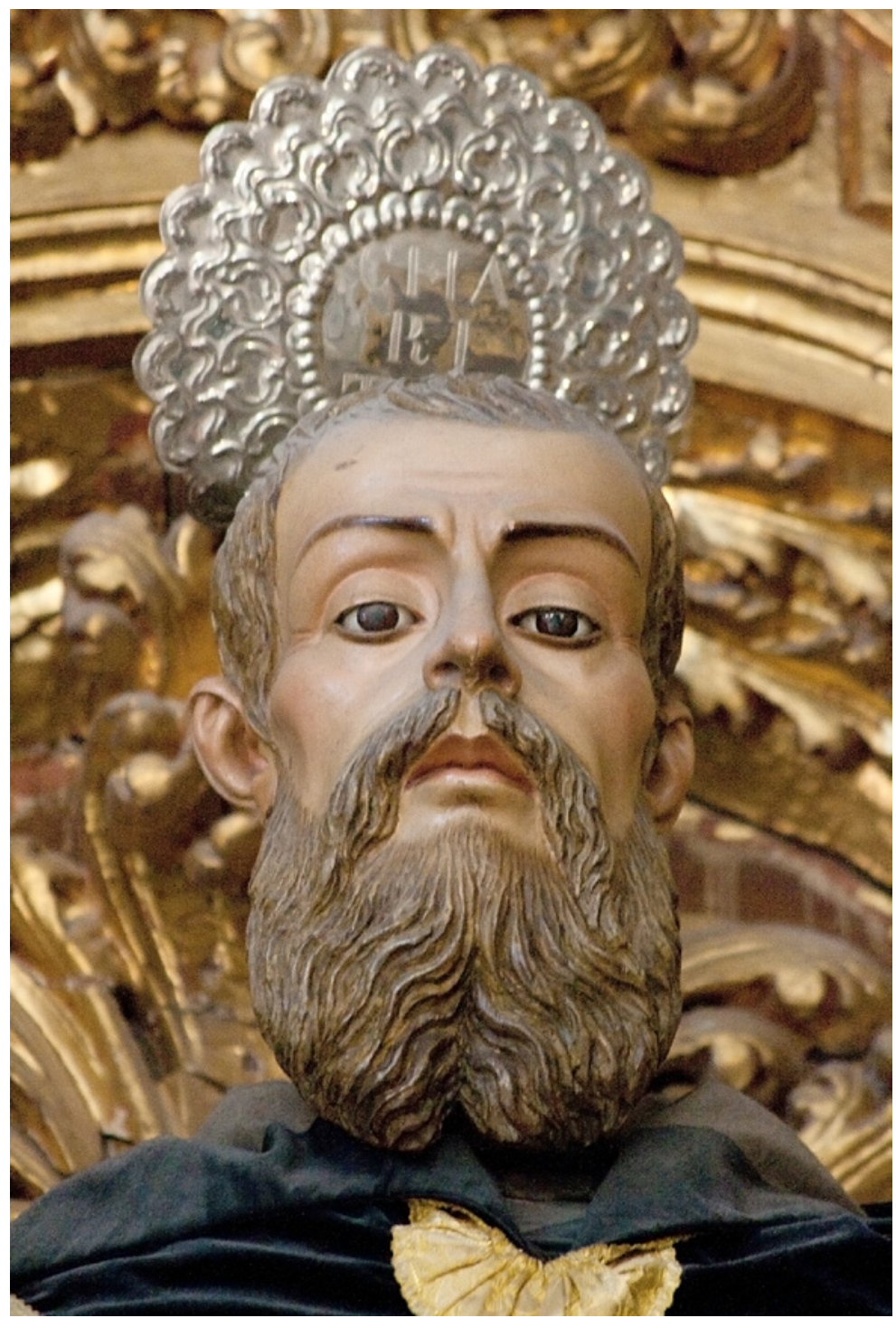

Figura 5. San Francisco de Paula (detalle), ¿Pedro Roldán el Mozo y Juan Caballero? Lucena, iglesia parroquial de Santo Domingo. 


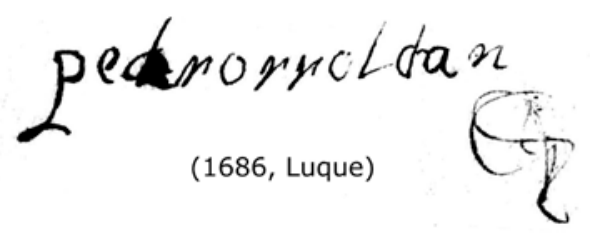

pecleroproldan

(1697, Archidona)

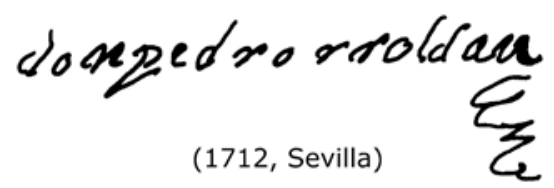

tped nonnoldan

(1686, Lucena)

dospderoproldau

(1700, Sevilla)

ig rornoldan

(1717, Sevilla)

Figura 6. Comparativa de las firmas de Pedro Roldán el Mozo (composición del autor). 


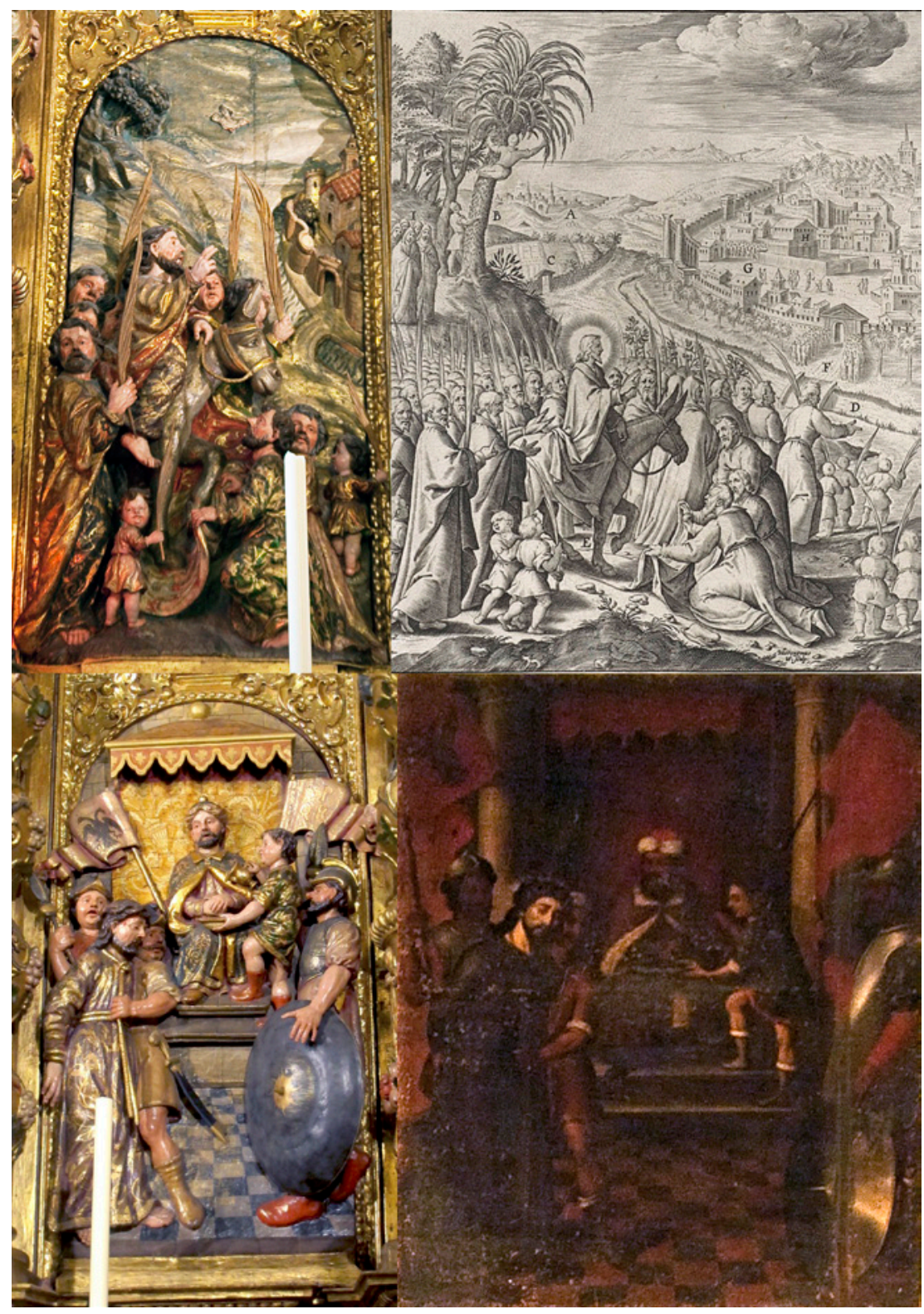

Figura 7. Comparativa de los relieves de la Entrada en Jerusalén y Jesús ante Pilatos del retablo del Nazareno de Osuna con el grabado de Hieronymus Wierix y una pintura anónima de la misma capilla. Fotos: Pedro J. Moreno de Soto y autor. 


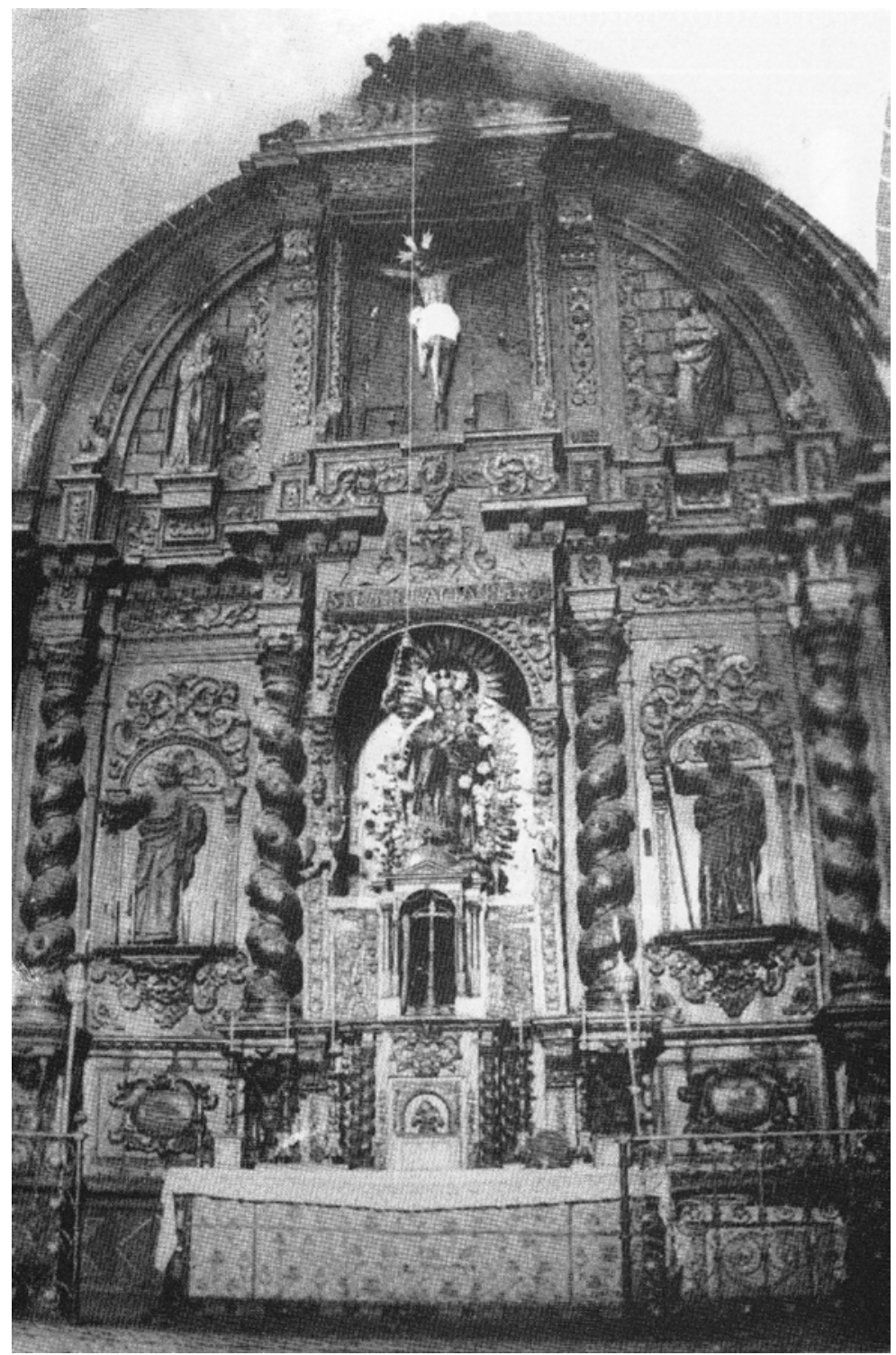

Figura 8. Retablo mayor (desaparecido), Pedro Roldán el Mozo y Pedro Guisado, 1712-1717, Calañas, iglesia parroquial de Nuestra Señora de la Concepción. 